\title{
'Knowledge about Religions' and Analytical Skills in Religious Education: Reflections from a Norwegian Context
}

Bengt-Ove Andreassen ${ }^{1}$

$\propto$ Religious education appears in many different models and varies between educational systems and national contexts. Theoretically, religious education is usually divided into confessional and non-confessional models. However, as several researchers have pointed out, the nonconfessional models can be 'marinated' in confessional religion. In most national contexts, regardless of the model on which it is based, religious education is intended to serve the promotion of social cohesion by way of promoting knowledge and understanding of the new multi-religious world. However, in official documents and scholarly literature, there is a taken-for-granted relationship between 'knowledge of religion' and such general aims. In the article, critical questions concerning this relationship will be raised.

Keywords: religious education, curriculum, 21st-century skills, Norway, epistemology 


\section{'Znanje o religijah' in analitične veščine v religijskem izobraževanju: razmisleki iz norveškega konteksta}

Bengt-Ove Andreassen

$\propto$ Religijsko izobraževanje se pojavlja v obliki različnih modelov ter se razlikuje med izobraževalnimi sistemi in nacionalnimi konteksti. V teoriji religijsko izobraževanje običajno delimo na nekonfesionalne in konfesionalne modele, vendar so - kot izpostavljajo številni avtorji - lahko nekonfesionalni modeli 'marinirani' v konfesionalni religiji. Ne glede na model, na katerem temelji religijsko izobraževanje, je to v večini nacionalnih kontekstov namenjeno podpori družbene kohezije na način, da promovira znanje in razumevanje novega multireligijskega sveta. V uradnih dokumentih in akademski literaturi pa obstoji samoumevnost odnosa med 'znanjem o religiji' in takšnimi splošnimi cilji. Članek kritično preučuje ta odnos.

Ključne besede: religijsko izobraževanje, kurikulum, veščine 21. stoletja, Norveška, epistemologija 
In this article, I aim to raise some critical reflections and questions regarding 'knowledge about religion' in religious education (RE). Based on examples from Norwegian RE, I will critically discuss what 'knowledge about religions' is and argue for the importance of analytical and interpretative skills in RE. The discussions will relate to an ongoing process of developing new curricula for RE in Norway, in which ideas from the $21^{\text {st }}$-century movement have been influential.

\section{Background - RE in the Norwegian educational system}

The background for this article is my work with RE in a Norwegian educational context. RE in Norway is based on an integrative model and thus a subject that is non-confessional and should include all pupils, regardless of religious or non-religious background (cf. Alberts, 2007). The Norwegian Education Act (Section 2-4) clearly states that the teaching should be critical, objective and pluralistic. ${ }^{2}$ In primary and secondary school (years 1-10), the subject is usually labelled 'KRLE', which is an abbreviation of Christianity, religion, secular world views and ethics (cf. The Norwegian Directorate for Education and Training, 2015). In upper secondary school (years 11-13), the subject is labelled 'Religion and Ethics' (Norwegian: Religion og etikk). In this article, I will use the term commonly used in English, 'RE' (Religious Education), when I write about RE in general and use 'KRLE' and 'Religion and Ethics' when I refer to each of the specific subjects.

In 2018, an extensive process of designing new curricula for all school subjects was underway in Norway. The process started in 2017 and was initiated at the political level, aiming to develop and improve already existing curricula. A primary aim was to design 'subjects for the future', inspired by recommendations from international institutions like the Organization for Economic Cooperation and Development (OECD). ${ }^{3}$ Presenting ideas for what a subject for the future might look like, these recommendations are highly influenced by the $21^{\text {st }}$ century skills movement. Related to RE, the question at stake is, of course, what an RE subject for the future looks like.

The background to this curriculum reform was formulated in an Official Norwegian Report, entitled The School of the Future. Renewal of Subjects and Competences (NOU, 2015, p. 8). A significant feature in this report is how ideas about $21^{\text {st }}$-century skills are translated into the context of Norwegian education

2 The Norwegian Education Act in English: https://www.regjeringen.no/contentassets/b3b9e92cce6742c39581b661a019e504/education-act-norway-with-amendments-entered-2014-2.pdf.

3 cf. OECD projects like Education 2030 (http://www.oecd.org/education/2030/) and documents like OECD (2018). 
policy (cf. Hilt, Riese, \& Søreide, 2019). When this report was delivered, the government had already started to prepare how curriculum reform should proceed. Firstly, a new Core Curriculum applicable to primary, secondary and upper-secondary school was presented in the summer of 2017.4 This will not be implemented before the fall of 2020, together with new curricula in each school subject. The new Core Curriculum (Chapter 2.5) states that the school should facilitate learning through three interdisciplinary themes: public health and livelihood, democracy and citizenship, and sustainable development. These interdisciplinary themes are integrated into each of the curricula for the various school subjects and are intended to serve the purpose of creating a connection between topics in each subject.

\section{The belief in 'knowledge about religions' in RE}

In curricula in different national contexts, in official documents and recommendations from international organisations, and in surprisingly much of the scholarly literature on RE, there is often a presumed idea that learning about religions leads to understanding and tolerance. In 2007, the Organization for Security and Co-operation in Europe (OSCE) issued the report, Toledo Guiding Principles on Teaching about Religions and Beliefs in Public Schools (OSCE, 2007). In this report, there are arguments that knowledge about religion(s) (and secular world views) is necessary in order to understand society, its history and culture, in both the past and present. In addition, it states that knowledge about religion 'has the valuable potential of reducing conflicts that are based on lack of understanding for others' beliefs' (cf. OSCE, 2007, pp. 76-77). The report says nothing about either the epistemological basis for this knowledge or skills that might be important in learning about religions.

Attempts to present important skills can be found in the Council of Europe publication, Religious Diversity and Intercultural Education: A Reference Book for Schools (Keast, 2007). In this reference book, different approaches in teaching RE are outlined, and, in some of these examples, skills for developing such competencies are discussed (i.e., Jackson, 2007, pp. 79-83; Milot, 2007, pp. 51-54). The same applies to the report, Signposts (Jackson, 2014, pp. 33-46), in which Robert Jackson outlines the 'interpretive approach' in RE. Inspired by interpretive anthropology and the works of Clifford Geertz, Jackson and his colleagues at Warwick University developed the 'interpretive approach' in RE

4 The new Core Curriculum has not been translated into English yet. Link to the Norwegian version: https://www.udir.no/laring-og-trivsel/lareplanverket/overordnet-del/. Link to English version: https://www.udir.no/lk2o/overordnet-del/?lang=eng 
in the late 1990s. However, the relation between knowledge, skills and general competencies also remains somewhat blurry in Jackson's work.

One might also say that the assumed relation between 'knowledge about religion(s)' is the main idea in the arguments for a non-confessional RE subject in public schools. Providing 'knowledge about religion', RE is expected to play a central role in addressing extremism (cf. Whitlock, 2017) and developing tolerance and understanding (cf. Jackson, 2012; Weissman, 2009). If one removes the idea that 'knowledge about religion' is a basis for such aims, one might say that the basis for a non-confessional RE is also removed. There is no doubt that the 'knowledge dimension' in RE is important. However, it is not a given that knowledge about religions automatically leads to understanding, respect and/or tolerance. Norwegian scholars Marie von der Lippe and Sissel Undheim (2017, pp. 14-15) have pointed out that there is no causality in knowledge about religions leading to understanding 'the other' or tolerance. In an English report, a similar paradox is pointed out: 'The paradox of education is that it has tremendous potential for both good and bad dependent on its use and implementation' (Gosh, Manuel, Chan, Dilmulati, \& Babaei, 2016, p. 17). The keywords are 'dependent on its use and implementation'. What pupils learn will depend on several factors: How the teaching is conducted, the framing of the teacher, dominating public discourses that serve as an interpretative reference for the pupils (i.e., news media and popular culture), and also the students' background. Nevertheless, 'knowledge of religions' is a step further than no knowledge of religion. The crucial point is what constitutes the 'knowledge of religions' and how this knowledge is framed in teaching.

\section{The strategic use of 'knowledge about religion' in RE curricula}

In relation to RE or any subject in school, there are always different views or ideas regarding the knowledge or ideas that should be included in a curriculum, i.e., what the pupils should learn. The arguments vary in accordance with what perspective one has or/and what main aims RE is intended to have. Arguments about the kind of knowledge pupils should acquire often relate to cultural history or cultural heritage; i.e., knowledge about religions is important in order to provide pupils with insight into their cultural background. This line of argumentation is often related to the idea and the discussion of 'religious literacy', which I will return to below. In this sense, 'knowledge about religion' is limited to knowledge about a specific religion. In the European context, that means knowledge about Christianity in some confessional version. 
A common educational perspective concerning 'knowledge about religion' is thus that emphasis should be placed on a specific religious tradition, with reference to cultural heritage. Cultural heritage is quite often related to an idea of identity formation, i.e., that getting to know your own history, your cultural background, is about getting to know who you are and the cultural tradition of which you are a part. In Europe, as mentioned above, this line of thinking is related to some kind of Christian confession. Researchers have pointed out how this kind of strategic use of 'knowledge about Christianity' is related to Norwegian cultural history (cf. Andreassen, 2014, 2017). A primary idea explicitly stated in the Norwegian curricula was that Christianity formed 'a deep current' within Norway's ('our') history (cf. Andreassen, 2014, pp. 268-269). In the current Core Curriculum (The Royal Ministry of Education, Research and Church Affairs, 1994) (which applies until 2020), Christianity was primarily related to Norwegian culture, and not viewed as a religion or a 'world religion'. This way of relating Christianity, the majority religion, to 'our culture' or 'our nation's history', is, firstly, a way of constructing knowledge about Christianity to be of special importance. Secondly, it relates Christianity to culture, i.e., something else compared to other religions that are oriented towards rules and regulations for its followers. Hence, religious traditions as 'religions' (or 'world religions') are more stereotypically constructed as something limiting 'our' way of life or 'our culture', rather than Christianity, which, in the Norwegian case, is described in the curricula as a part of Norwegian culture. These tendencies are also present in the Nordic countries (Denmark, Sweden and Norway; Finland is an exception) (cf. Andreassen, 2013; Berglund, 2013; Husebø, 2014; Jensen \& Kjeldsen, 2013). In these three countries, the RE subject in school is considered or intended to be non-confessional. Still, there is a quantitative bias towards Christianity, and Christianity is the only religion which is related to national history and cultural identity.

No one argues against the fact that Christianity has been a central part of history and culture in Nordic countries since the $11^{\text {th }}$ century. When Christianity is given more space in RE in school, with reference to historical significance, it indicates a perspective that emphasises historical knowledge. The opposite, a lack of historical knowledge, poses a danger because it makes it difficult - almost impossible - to have insight into today's society. Consciousness about history, in contrast, provides an insight into a binding continuity between past and present and, thus, understanding and insight into Norwegian society. Historical knowledge provides insight into heritage, tradition, and roots, and might also relate to identity. With consciousness about history linked to the position of Christianity in Norwegian history, the goal seems to be to counteract contemporary historical changes that do not provide as much importance to the knowledge of Christianity. 
In the verdict against the Norwegian state in 2007, the European Court of Human Rights in Strasbourg decided that there can be a quantitative bias (towards Christianity) in a curriculum, as long as this does not lead to a qualitative bias (Andreassen, 2013, pp. 144-145). Even with a quantitative bias, it might pass as a non-confessional subject in accordance with regulations on religious freedom and human rights. Thus, religions must be treated as qualitatively equal and not be qualitatively rated. This is, of course, complicated, and in most national contexts, it is a long way from the political level, deciding and discussing these issues, to teaching in the classroom. My point here is simply to show that there are (at least) two ways of arguing, and this might lead to slightly different ideas of why and how specific religions should be included in a curriculum. The emphasis on 'knowledge about Christianity', in Norway, Denmark, and Sweden, is strategically related to cultural heritage and the nation's history. 'Knowledge about other religions' then becomes knowledge of 'the others' and not 'us'. Thus, a pattern might appear in the 'knowledge about religions': that it counteracts intentions of social cohesion or tolerance.

'Knowledge about religions' is also to a large extent embedded in the socalled 'World Religion Paradigm' (cf. Cotter \& Robertson, 2016). That means that when 'other religions' are mentioned besides Christianity, the 'world religions' are found: Judaism, Islam, Buddhism, and Hinduism. Suzanne Owen (2011) has pointed out that the 'world religion paradigm' is widely and rather unquestioningly adopted in RE in England. In reference to Owen (2011), Wanda Alberts (2017) has argued that this is also the case for many other countries. And she adds: 'In the European context, the world religions paradigm may even be said to be the framework for the representation of religions in school, be it in separative (different versions of confessional RE and so-called "alternative subjects") or integrative (one subject for all pupils together) contexts' (Alberts, 2017, p. 451). Both Alberts and Owen comment that the usual pattern is Christianity + 'other religions' or 'other world religions'. The 'world religion paradigm' might be seen as an interpretive frame that serves to position Christianity on top or as the prototype of religion, which other religions should be understood in reference to.

\section{Strategic use of knowledge in religious literacy arguments}

The very idea behind different arguments about the importance of linking 'knowledge about religion' to cultural history can be related to the idea of 'religious literacy.' The term 'religious literacy' has been used in the debate on

5 The sections/paragraphs on religious literacy and cultural heritage draw on an article written in Norwegian (Andreassen, 2017, pp. 46-48). 
religious education in England since the 1990 s (cf. Jackson, 2004, p. 75) and is more recently used in various ways by religious studies scholars (see, for example, Fujiwara, 2010; Moore, 2007; Prothero, 2007). The use of the term is not unambiguous, but the main content is related to an understanding of how knowledge about religion is essential for having insight into one's own culture and history. The term, however, is not only aimed at historical relationships alone but about how such knowledge also provides insight into today's society. For example, in an American context, Stephen Prothero (2007) adds great importance to knowledge about the Bible. His reasoning is that American's inadequate knowledge of the Bible makes it harder to understand their own society. Hector Avalos (2009) has criticised Prothero's (2007) argument and adds that more emphasis on Bible knowledge is not only about being conscious of the Bible's central position in American history but about highlighting and maintaining a particular perspective on how American society and American history should be understood today. Avalos (2009) also raises the question of whether the lack of Bible knowledge actually might help solve power structures related to, for example, Christian churches. Thus, 'deficient' Bible knowledge can have an emancipatory (liberating) function, according to Avalos. Alternatively, more nuanced: if your attention is too focused on how the Bible has influenced American history, you miss other important factors, and you become 'caught' in a pattern of detecting the Bible's influence.

The questions raised by Avalos also show that knowledge is not neutral but might be interpreted and used in different ways. It is about how 'knowledge about the Bible' is being framed. In the academic study of history, theoretical discussions about creating history and how people might be seen as active agents in creating histories, and thus in a position to create history, have gained much attention (cf. Kean \& Ashton, 2009, p. 1). History, as 'knowledge of religion', has to be created and defined as 'knowledge'. In the school system, there is no doubt that curricula are powerful tools in creating knowledge. A curriculum also creates 'important knowledge', thus creating a hierarchy of knowledge. From a study of religions point of view, an argument would be that it is, of course, relevant to know something about religious texts, such as the Bible, as constituting different religious traditions and as examples of religious innovation and change. Several of the competence goals regarding the Bible in the current Norwegian KRLE curriculum concern the students having insight into specific texts and that there is a clear meaning in them. ${ }^{6}$ This suggests a more

6 One of the formulations in the main subject area, Christendom after $10^{\text {th }}$ grade, states that 'Pupils should be enabled to discuss and elaborate on selected biblical texts from the Prophets, the poetic biblical texts in the Bible, the Words of Wisdom, one Gospel and one of the Letters of Paul, and explain the distinctive characteristics and main ideas of these' (The Norwegian Directorate for Education and Training, 2015, p. 8). 
normative interpretation and understanding of the Bible, not just about pupils gaining religious literacy or insight into their cultural heritage. It is about getting to know specific texts, specific interpretations, which the Norwegian state defines as important. For the sake of nuance, however, one should add that the curriculum also mentions texts from other religious traditions. ${ }^{7}$ Still, other religious texts are referred to more generally, and specific parts of the texts are not mentioned, only the Koran and Hadiths (Islam), or 'selected texts from Hindu and Buddhist written traditions' (The Norwegian Directorate for Education and Training, 2015, p. 6).

My point is that knowledge in an RE curriculum is not 'just' about 'historical facts' to provide insight into cultural heritage or improve religious literacy. It is also about how one wants to use knowledge and use history. In RE, it is about the selection of 'important' or 'relevant' knowledge about religion that appears in the curricula, and how this is related to religious literacy and communicated as important for cultural identity or national history. Danish historian Bernard Eric Jensen (2009) points out that the past can be used in different ways and with different purposes. Central to the history subject is that history is not something objectively given that can be conveyed neutrally. History and history dissemination are about something being identified as 'history' or 'past', and thus also communicated as something central or essential. For something in the past to appear relevant in the present, it is required that the past be made alive and that it can be perceived as 'authentic' (Kruse \& Warring, 2015, p. 109). 'History', 'tradition', and 'cultural heritage' do not exist in themselves but must be actively defined and maintained. Study-of-religions researchers have pointed out that religiosity is closely interwoven with an active construction and maintenance of traditions of religion (cf. Hervieu-Léger, 1999). In light of established historical perspectives, the emphasis on Christianity as cultural heritage in RE curricula in the Nordic countries concerns maintaining awareness of a majority religion and a cultural tradition, not simply learning some historical facts. This becomes more evident when one takes into account how references to or knowledge about Old Norse religions are absent in the current RE curricula.

\section{The challenges of the $21^{\text {st }}$-century skills movement in RE}

In a paper on teaching religion at universities and university-colleges, the study-of-religions scholar, Jonathan Z. Smith (1938-2017) ([1991] 2013, p.

7 Regarding Islam, after $7^{\text {th }}$ grade, it states that 'Pupils should be able to explain what the Koran and Hadith are and talk about central stories from Islamic faith' (The Norwegian Directorate for Education and Training, 2015, p. 7). 
13), writes, 'There is nothing that must be taught, there is nothing that cannot be left out'. Challenged to define a core issue in liberal education, Smith formulates, 'training in argument about interpretation' (Smith, [1991] 2013, p. 14). One might argue that Smith put more emphasis on skills than acquiring knowledge, aiming to enable his students to think critically, in the sense of becoming aware of how, for example, a religious text can be interpreted in different ways, rather than learning simple facts, such as the founder of Sikhism was, according to Sikh tradition, Guru Nanak (1469-1539), and so forth. Smith's idea is to relate knowledge to interpretation and, consequently, to power. In this approach to teaching, Smith also formulates two rules. The first is that teaching must be 'organised around the notion of argument and the insistence that the building blocks of argument remain constant: definitions, data, classifications, and explanations' (Smith, [1991]2013, p. 17). The second rule is: 'Nothing must stand alone' (ibid.). By that, Smith explains that a second-order text should have a conversation partner in another text that deals with the same issue. Such a juxtaposition might reveal differences in arguments and interpretation. Through his two rules, one gains a sense of what Smith's idea of 'training in argument about interpretation' is.

The above citation of Smith, that 'There is nothing that must be taught, there is nothing that cannot be left out', can in many ways make you think of the basic ideas in the so-called $21^{\text {st }}$-century skills movement. Advocates of the $21^{\text {st }}$-century skills movement argue that schooling for the future should emphasise skills that will be important in pupils' future, in higher education and in working life (cf. Prensky, 2010; Trilling \& Fadel, 2009). These competencies also provide a 'learning for life', not just 'learning for schools', thus implying that knowledge-oriented teaching is not relevant for the future. This distinction is but one example of a number of binary oppositions constructed in the discussion about $21^{\text {st }}$-century skills (Greenlaw, 2015, p. 896). Focus on content (knowledge) is often related to teacher-oriented teaching (vs student-centred learning), dominated by facts and principles (vs questions and problems) and, hence, theoretical (vs directed towards practice and future) (ibid.). The list might be longer. The point is that the binary oppositions create a dichotomy between traditional ('teacher-centred and hierarchical') teaching and progressive ('student-centred and inclusive') teaching. This might result in a polarised debate, thus being not very constructive.

I do not know of any education system that does not emphasise some kind of skills. The question at stake is rather if and/or how skills, instead of knowledge, are emphasised. In policy documents, the focus on skills is removed from the knowledge they are supposed to produce. Skills like analysis or 
interpretation are very rarely put forward in the $21^{\text {st }}$-century skills movement. Instead, the focus is on more technical skills like critical thinking, creativity, collaboration, communication, information literacy, media literacy, technology literacy, flexibility, leadership, initiative, productivity and social skills. ${ }^{8}$ One can easily agree that such skills are essential in schools. However, there is a danger of them becoming 'fast' or 'quick' skills that can be marked as 'done' on a teacher's checklist. Performing an analysis or interpretation of a religious text or other material from a religious tradition is slow and takes time.

In Norway, but also in other countries, the impact of global organisations, particularly the OECD, ${ }^{9}$ has influenced the school system (cf. Hovdenak \& Stray, 2015, p. 55). This has resulted in stronger accountability requirements, the implementation of a national framework for quality control, and a curriculum (in 2006) formulating measurable competence goals, rather than content specifications. Norwegian scholars Hilt, Riese, and Søreide (2019, p. 385), have used the term 'vernacular globalisation', to describe the influence of global organisations in Norway. This term describes how global ideas are contextualised in a national educational system.

Returning to Smith, his statement, cited above, that 'There is nothing that must be taught, there is nothing that cannot be left out', can be used to legitimise a curriculum without any specific reference to what the particular content of the knowledge should be, i.e., traditional teaching goals, such as 'Knowledge about five pillars of Islam', 'Knowledge about the Reformation in Europe', or 'Knowledge about the Church of Norway'. 'Knowledge about religion' can be quite different and, at some point, include something (some religions) and portray a religion through a religious elite or extremists, as well as exclude something (some religions) and leave out the diversity of people in a religious tradition.

The crucial point is how 'knowledge about religions' is being framed and made an object for various interpretations, as Smith ([1991]2013) pointed out. The competency to map and analyse different interpretations, and thus representations, is a kind of competency that I will argue is not given sufficient attention in the $21^{\text {st }}$-century skills movement. To do a critical reading in order to be aware of different interpretations of the same, demands depth, time, and

8 This website gives a quick introduction to all the skills included in the $21^{\text {st }}$ skills movement: https:// www.aeseducation.com/career-readiness/what-are-21st-century-skills.

9 A recent OECD report (a position paper), 'The Future of Education and Skills' (OECD, 2018), can serve as an example of how the OECD highlights some areas of competency or skills. In this report, three challenges are put forward, needing 'new solutions in a rapidly changing world': environmental, economic and social (OECD, 2018, p. 3). In order to solve these challenges, pupils must learn to be agents: 'Future-ready students need to exercise agency, in their own education and throughout life. Agency implies a sense of responsibility [...]' (OECD, 2018, p. 4). 
a qualified teacher. It also differs from the typical competency regarding the ability to deal with the vast amounts of information that the 'knowledge society' produces. An important argument in the $21^{\text {st }}$-century skills movement is that Internet technology provides a challenge in its vast ocean of information. In $\mathrm{RE}$, one might say that religion and religions on the Internet will help students understand that there are lots of ways being a Christian, a Muslim or a Hindu. However, it is a significant challenge, as Greenlaw and Fox (2007, p. 70) formulate it, 'Information appears indiscriminately, directed at no one particular, in enormous volume at high speeds, and disconnected from theory, meaning, or purpose. For the RE teacher, the task is to provide students with theory and an interpretative frame. One must develop analytical and interpretative skills in order to make some sense - if that is possible - of all the information about religious traditions on the Internet (and elsewhere), as Smith argues. Analysing how knowledge can be - and is being - used for different purposes is about providing the pupils with a frame that can relate the awareness of different interpretations to power, to equality, to civilisations. Greenlaw (2015, p. 897) has criticised the $21^{\text {st }}$-century skills metanarrative for undervaluing the role of the teacher as an experienced expert who can frame the students' learning by contextualising and theorising along with the students. I will relate Greenlaw's criticism of what I see as the $21^{\text {st }}$-century skills movement's avoidance of dealing with epistemological questions. The reason is most probably that the $21^{\text {st }}$ century movement does not wish to spend much time on knowledge, because that is related to 'traditional teaching, which, basically, is seen as old fashioned and something one wants to discard. The result, in my opinion, is that the $21^{\text {st }}$ century skills movement only scratches the surface in dealing with epistemological questions.

An obvious explanation for why the $21^{\text {st }}$-century movement avoids epistemological questions is, of course, that the focus is on overarching or general competencies, literally skills, that might apply for every school subject. Then there is no time or place to deal with epistemological questions. As global institutions such as the OECD seemingly get more power in making recommendations for educational systems, thus influencing national educational systems, it is crucial to be aware firstly how (and by whom) such recommendations have been produced and, secondly, how they are interpreted and applied in specific educational systems. The latter has been characterised by Weninger (2017) as 'the "vernacularisation" of global education policy'.

For the sake of nuance, there is, of course, an important side to global education policies, as they might prevent nationalism and exclusivism in national curricula. However, these policies also contain valorised ideas of education and 
are not neutral. They emphasise some things (skills or competencies) as important and thus leave something out.

\section{The 'vernacularisation' of global education policy in Norway - designing an RE subject for the future}

In the Norwegian case, in the white papers and documents that form the background of the new curricula that will be implemented in 2020 , one can almost sense a fear that the curricula might become outdated too fast. When the first drafts of the new curricula were presented in early 2018 , one could see the influence of the $21^{\text {st }}$-century skills movement, through a systematic focus on general competencies. The competencies do not vary much from subject to subject and focus on the fact that pupils should be enabled to explore, gather information, explain, present (to others, written and orally), think critically, analyse, make comparisons and critically assess information and knowledge.

The first job for the committees that were organised in 2018 to develop a new RE curriculum was to transfer the interdisciplinary themes, which were presented in the Core Curriculum, into five 'core elements'. This resulted in these 'core elements' ${ }^{10}$ for RE: 1 ) awareness ${ }^{11}$ of religions and secular world views, 2) exploration of religions and (secular) world views with different (research) methods, 3) exploration of existential questions and answers, 4) the ability to take another's perspective, and 5) ethical reflection. These 'core elements' apply to RE both in primary and secondary (the KRLE subject) and in upper secondary (the Religion and Ethics subject) schools.

The first two of the 'core elements' deal explicitly with religion. 'Awareness of religions and secular world views' are elaborated in this way:

The subject will provide knowledge and understanding of religions and secular world views locally, nationally and globally, and at the individual, group and tradition levels. Pupils should also gain insight into how religions and secular world views form part of historical processes and are linked to social changes and cultural heritage. The pupils will become familiar with the diversity of religions and secular world views, as well as the diversity within the different traditions. The subject will provide a basis for reflection on majority, minority, and indigenous perspectives in Norway. (Pedlex, 2018, p. 69, my translation)

11 In Norwegian documents, it does not say knowledge (Norwegian, kunnskap) but awareness (Norwegian, kjennskap). 
The second, 'Exploration of religions and secular world views with different (research) methods', reads:

Pupils should be able to examine and explore religions and secular world views as complex phenomena, through the use of varied (research) methods. Their understanding of religions and secular world views is deepened and challenged through analysis of and critical reflection on sources, norms and the power of definition. Knowledge of different views and definitions of religions and secular world views is part of the core element and is essential for understanding and managing diversity. (Pedlex, 2018, p. 70, my translation)

The 'core elements' clearly signal that religion and secular world views are things that appear different in different contexts and discourses. The approach is critical and aims to explore different sides to religions and secular world views. The idea that pupils should learn to analyse and think critically about sources, norms and the power of definition, I find very important. In the core elements lie important ideas about dealing with epistemological questions that pupils will face and can only learn about in RE.

Based on these 'core elements', the draft issued in March 2019 by the curriculum committee for RE presented curricula for KRLE and Religion and Ethics, introducing new formulations for competencies in RE, i.e., what should be taught. In the latest draft, there are eleven formulations about competencies in the curriculum for stages 8-10 and thirteen in the curriculum for uppersecondary schools. ${ }^{12}$ The formulations of competencies appear to be similar for secondary and upper-secondary schools, albeit on a more complex taxonomical level in upper-secondary schools, with competencies such as analysis and comparison, which do not appear in the secondary school curriculum.

Even if there will also be a quantitative bias towards Christianity in the curriculum for 2020 , and the draft implies that a primary focus might be more on general competencies, I find it significant that competencies concerning analysis and interpretation are included in the core elements. The pupils should be enabled to explore, explain, present, reflect (think), use, and critically assess information and knowledge about religion and secular world views.

12 However, the Norwegian educational context has its paradoxes. In 2015, it was politically decided that 'About half of the teaching time of the subject will be used for Knowledge of Christianity' (Andreassen, 2013, p. 148; Norwegian Directorate for Education and Training, 2015, p. 2). This will also apply to the new curriculum in KRLE in 2020 and was something that the curriculum committee working with the new curriculum could alter. This does not apply to Religion and Ethics in upper-secondary school. This quantitative emphasis on Christianity in KRLE is related 'to the significance of Christianity as cultural heritage in our [the Norwegian] society' (ibid.). 
Developing general understanding and being able to take another's perspective are also part of the skills and competencies. For Religion and Ethics in uppersecondary schools, the skills and competencies are similar but somewhat more advanced, as the pupils should be enabled to explore, describe, investigate, explain and problematise, analyse, and compare information and knowledge about religions and secular world views.

I find the new curricula in RE in Norway interesting. How the final documents will look remains to be seen. However, there will definitely be a need for competent teachers with specialised training in RE in order to approach the ideas formulated in the core elements. Additionally, there is a risk that teaching in RE, influenced by the $21^{\text {st }}$-century skills movement, will focus on general competencies and skills, without dealing with the more epistemological questions in RE, such as questions of representation and power.

\section{Closing remarks}

'Knowledge about religion' might be described as a nodal point in teaching RE. However, in curricula, ideas and intentions about how this knowledge should be framed and used are not unambiguous. It may be related to general aims of creating social cohesion, understanding and tolerance, and it can be related to a strategic use of what is essential in a nation's cultural heritage. I find it interesting that some of the skills in the Norwegian curricula that are currently developed find their parallel in the thinking of the study-of-religion scholar, Jonathan Z. Smith. Applied in RE, the skills advocated by Smith are necessary, in order to develop and frame 'knowledge about religion' and how it may vary in different contexts and might be interpreted differently. An RE subject for the future must, of course, draw on general competencies and skills that are also relevant in other school subjects. In addition, competencies and skills that analyse religion and secular world views as epistemological entities, subject to strategic interpretation, are crucial for maintaining RE's legitimacy as a separate and vital school subject in public education.

\section{References}

Alberts, W. (2007). Integrative religious education in Europe. A study-of-religions approach. Berlin: De Gruyter.

Alberts, W. (2017). Reconstruction, critical accommodation or business as usual? Challenges

of criticisms of the World Religions Paradigm to the design of teaching programmes in the study of religions. Method and Theory in the Study of Religion, 29(4-5), 443-458. doi:https://doi. 
org/10.1163/15700682-12341404

Andreassen, B.-O. (2013). Religion education in Norway: Tension or harmony between human rights and Christian cultural heritage? Temenos, 49(2), 137-164.

Andreassen, B.-O. (2014). Christianity as culture and religions as religions. An analysis of the core curriculum as framework for Norwegian RE. British Journal of Religious Education, 36(3), 265-281. Andreassen, B.-O. (2017). Hvordan kan vi forstå kristendommens sentrale plass i skolens religionsfag? [How can we understand Christianity's central position in RE?]. In M. von der Lippe \& S. Undheim (Eds.), Religion i skolen. Didaktiske perspektiver på religions- og livssynsfaget (pp. 35-53).

Oslo: Universitetsforlaget.

Avalos, H. (2009). Is biblical illiteracy a bad thing? Reflections on bibliolatry in the modern academy. Council of Societies for the Study of Religion. The CSSR Bulletin, 38(2), 47-52.

Berglund, J. (2013). Swedish religion education: Objective but marinated in Lutheran Protestantism? Temenos, 49(2), 165-184.

Cotter, C. R., \& Robertson, D. G. (2016). The world religions paradigm in contemporary religious studies. In C. R. Cotter \& D. G. Robertson (Eds.), After world religions. Reconstructing religious studies (pp. 1-20). London, UK: Routledge.

Fujiwara, S. (2010). On qualifying religious literacy. Recent debates on higher education and religious studies in Japan. Teaching Theology and Religion, 13 (3), 223-236. doi:https://doi.org/10.1111/j.14679647.2010.00615.X

Gosh, R., Manuel, A., Chan, W. Y., Dilmulati, D., \& Babaei, M. (2016). Education and security. A global literature review on the role of education in countering violent religious extremism. Tony Blair Institute for Global Change. Retrieved from https:/institute.global/sites/default/files/inline-files/ IGC_Education\%2oand\%2oSecurity.pdf

Greenlaw, J. (2015). Deconstructing the metanarrative of the $21^{\text {st }}$ century skills movement.

Educational Philosophy and Theory, 47(9), 894-903. doi:10.1080/00131857.2015.1035156

Greenlaw, J. C., \& Fox, M. (2007). The New Brunswick dedicated notebook research report: Final report. Fredericton: New Brunswick Department of Education.

Hervieu-Léger, D. (1999). Religion as memory. Reference to tradition and the constitution of a heritage of belief in modern societies. In J. G. Platvoet \& A. L. Molendijk (Eds.), The pragmatics of defining religion. Contexts, concepts and contests (pp. 72-93). Leiden: Brill.

Hilt, L. T., Riese, H., \& Søreide, G. E. (2019). Narrow identity resources for future students: The $21^{\text {st }}$ century skills movement encounters the Norwegian education policy context. Journal of Curriculum Studies, 51 (3) 384-402. doi:10.1080/00220272.2018.1502356

Hovdenak, S. S., \& Stray, J. H. (2015). Hva skjer i skolen? En kunnskapssosiologisk analyse av norsk utdanningspolitikk fra 199o-tallet og frem til i dag [What happens in school? A KnowledgeSociological analysis of Norwegian educational policies from the 1990 os until today]. Bergen: Fagbokforlaget.

Husebø, D. (2014). Tro- og livssynsfag i Skandinavia - en sammenligning [RE in Scandinavia - a comparison]. Norsk pedagogisk tidsskrift, 98(5), 364-374. 
Jackson, R. (2004). Rethinking religious education and plurality. London, UK: Routledge Falmer. Jackson, R. (2007). The interpretive approach. In J. Keast (Ed.), Religious diversity and intercultural education: A reference book for schools (pp. 79-9o). Strasbourg: Council of Europe Publishing. Jackson, R. (2012). The interpretive approach as a research tool: Inside the REDCo project. In R. Jackson (Ed.), Religion, education, dialogue and conflict. Perspectives on religious education research (pp. 84-102). London, UK: Routledge.

Jackson, R. (2014). Signposts - Policy and practice for teaching about religions and non-religious world views in intercultural education. Strasbourg: Council of Europe.

Jensen, B. E. (2009). Usable pasts: Comparing approaches to popular and public history. In P. Ashton \& H. Kean (Eds.), People and their pasts. Public history today (pp. 42-56). New York, NY: Palgrave Macmillan.

Jensen, T., \& Kjeldsen, K. (2013). RE in Denmark - Political and professional discourses and debates, past and present. Temenos, 49 (2), 185-223.

Kean, H., \& Ashton, P. (2009). Introduction. In P. Ashton \& H. Kean (Eds.), People and their pasts. Public history today (pp. 1-20). New York, NY: Palgrave Macmillan.

Keast, J. (Ed.) (2007). Religious diversity and intercultural education: A reference book for schools. Strasbourg: Council of Europe Publishing.

Kruse, T., \& Warring, A. (2015). Historiebrug på kryds og tværs - afrunding [Crisscross use of history - a summary]. In T. Kruse \& A. Warring (Eds.), Fortider tur/retur. Reenactment og historiebrug (pp. 109-113). Fredriksberg: Samfundslitteratur.

Lippe, M. von der, \& Undheim, S. (2017). Hva skal vi med et felles religionsfag i skolen? [Why common compulsory RE in school?]. In M. Von der Lippe \& S. Undheim (Eds.), Religion i skolen. Didaktiske perspektiver på religions- og livssynsfaget (pp. 11-24). Oslo: Universitetsforlaget. Milot, M. (2007). Co-operative learning. In J. Keast (Ed.), Religious diversity and intercultural education: A reference book for schools (pp. 51-56). Strasbourg: Council of Europe Publishing. Moore, D. (2007). Overcoming religious illiteracy. A cultural studies approach to the study of religion in secondary education. New York, NY: Palgrave MacMillan.

The Norwegian Directorate for Education and Training (2015). Curriculum for knowledge of Christianity, religion, philosophies of life and ethics [KRLE]. Oslo: Norwegian Directorate for Education and Training. Retrieved from https://www.udir.no/klo6/RLE1-02?lplang=http://data.udir. no/klo6/eng

NOU - Official Norwegian Reports [Norske offentlige utdredninger]. (2015). The school of the future. Renewal of subjects and competences. Oslo: Ministry of Education and Research.

OECD (Organisation for Economic Co-operation and Development). (2018). The future of education and skills. Retrieved from https://www.oecd.org/education/2030/E2030\%20Position\%20Paper\%20 (05.04.2018).pdf OSCE (Organisation for Security and Co-operation in Europe). (2007). Toledo guiding principles on teaching about religions and beliefs in public schools. Warsaw: OSCE/ODIHR. Retrieved from https:// www.osce.org/odihr/29154?download=true 
Owen, S. (2011). The world religion paradigm. Time for a change. Arts and Humanities in Higher Education, 10(3), 253-268. doi:10.1177/1474022211408038

Pedlex (2018). Dybdeloering og kjerneelementer i fag [Depth learning and core elements in school subjects]. Oslo: Pedlex.

Prensky, M. (2010). Teaching digital natives: Partnering for real learning. Thousand Oaks, CA:

Corwin.

Prothero, S. (2007). Religious literacy: What every American needs to know - and doesn't. New York, NY: Harper Collins.

The Royal Ministry of Education, Research and Church Affairs. (1994). Core curriculum. Oslo: The Ministry. Retrieved from https://www.udir.no/globalassets/filer/lareplan/generell-del/core_ curriculum_english.pdf

Smith, J. Z. ([1991] 2013]. The introductory course: Less is better. In C. I. Lehrich (Ed.), On teaching religion. Essays by Jonathan Z. Smith (pp. 11-19). Oxford, UK: Oxford University Press.

Trilling, B., \& Fadel, C. (2009). $21^{\text {st }}$ century skills: Learning for life in our times. San Francisco, CA: Jossey-Bass.

Weissman, D. (2009). Teaching religion in an inter-religious context: A form of peace-building. In L. Roos \& J. Berglund (Eds.), Your heritage and mine. Teaching in a multi-religious classroom (pp. 121-132). Uppsala: Swedish Science Press.

Weninger, C. (2017). The "vernacularization" of global education policy: Media and digital literacy as twenty-first century skills in Singapore. Asia Pacific Journal of Education, 37(4), 500-516. doi:10.1080 /02188791.2017.1336429

Whitlock, A. (2017). The role of religious education in addressing extremism. In M. Castelli \& M. Chater (Eds.), We need to talk about religious education. Manifestos for future RE (pp. 185-200). Jessica Kingsley Publishers: London.

\section{Biographical note}

Bengt-Ove Andreassen, $\mathrm{PhD}$, is a professor in the field of study of religions (with didactics of religions as one of his specialties) at the Department of Education, UiT - The Arctic University of Norway. His main areas of research are: curriculum and textbook analysis, representations of religions in $\mathrm{RE}$, religion in educational policies, and the professional development of RE teachers. 